\title{
Assessing the agroclimatic potentiality in Indian Sundarbans for crop planning by analyzing rainfall time series data
}

\section{ARGHA GHOSH ${ }^{1 *}$, MANOJ KUMAR NANDA ${ }^{1}$, DEBOLINA SARKAR ${ }^{1}$, SUKAMAL SARKAR ${ }^{2}$, KOUSHIK BRAHMACHARI ${ }^{2}$ and KRISHNENDU RAY ${ }^{3}$}

\author{
${ }^{1}$ Department of Agricultural Meteorology and Physics, ${ }^{2}$ Department of Agronomy, Bidhan Chandra KrishiViswavidyalaya, \\ Mohanpur - 741252, West Bengal; \\ ${ }^{3}$ Sasya ShyamalaKrishiVigyan Kendra, Ramakrishna Mission Vivekananda Educational and Research Institute, Arapanch, \\ Sonarpur, West Bengal, India \\ *Corresponding author email: ghoshargha4@gmail.com
}

\begin{abstract}
In order to assess the climatological risk in terms of the dry week probabilities and length of the growing period of Indian Sundarbans region for successful crop planning, the present study was conducted using long term rainfall data from 1984 to 2018 received in Gosaba CD (Community Development) block of Indian Sundarbans. The probability of a rainfall events with $25 \%, 50 \%, 75 \%$ probabilities were estimated. Markov Chain model was used to estimate the initial, conditional probabilities of dry and wet weeks along with the probability of two consecutive wet and dry weeks considering $10 \mathrm{~mm}$ and $20 \mathrm{~mm}$ rainfall thresholds. Length of growing period (LGP) was calculated using Moisture adequacy index computed by the soil water balance method of Thornthwaite and Mather. Weekly rainfall varied from 1.11 $\mathrm{mm}$ in $51^{\text {st }}$ Standard Meteorological Week (SMW) with standard deviation of \pm 3.41 to $88.49 \mathrm{~mm}$ in $29^{\text {th }}$ SMW with standard deviation of $\pm 58.19 .50 \%$ chance of getting more than $20 \mathrm{~mm}$ and $10 \mathrm{~mm}$ weekly rainfall was observed from $20^{\text {th }}(23.37 \mathrm{~mm})$ to $41^{\text {st }} \mathrm{SMW}(30.64 \mathrm{~mm})$ and $17^{\text {th }}(14.63 \mathrm{~mm})$ to $42^{\text {nd }} \mathrm{SMW}$ $(16.87 \mathrm{~mm})$ respectively. The risk of dry spells was very higher from $42^{\text {nd }}$ to $17^{\text {th }} \mathrm{SMW}$. Average LGP of the study area was 237.4 days with standard deviation of \pm 29 .88.Probability of a week being stress free growing period and moderately drought period was more than $50 \%$ from $18^{\text {th }}$ to $48^{\text {th }} \mathrm{SMW}$ and $49^{\text {th }}$ to $5^{\text {th }}$ SMW respectively. Grass pea, potato with straw mulch and green gram can be included in the rice based cropping system during winter and summer seasons for sustainable intensification of the cropping systems in Indian Sundarbans region.
\end{abstract}

Keywords: Crop planning, Indian Sundarbans, LGP, Markov chain model, rainfall probability

Indian agriculture is largely dependent on monsoon rainfall which varies widely in space and time. Rainfall, due to its erratic nature is considered as the major yield limiting factor in the tropical countries particularly in case of rainfed farming. Nearly, $80 \%$ of the total annual rainfall of India is received during monsoon seasons (June to September) and uncertainty in the monsoon rainfall causes yield variability. (Kumar and Bhardwaj, 2015; Deo et al., 2015; Dugal et al., 2018). The monsoon rainfall pattern has been changed now a days as a consequence of climate change and thereby occurring frequent early, mid or late season drought. Sequence of dry and wet periods along with the onset and withdrawal of monsoon rainfall determine the success or failure of a crop (Manikandan et al., 2017; Dash and Shatpathy, 2018).Uneven temporal distribution of rainfall is harmful for crop growth and development. Monthly and weekly rainfall intensity and distribution should be monitored to identify the optimum time for crop sowing and other agricultural operations (Mehta and Chandra, 2016).

Agroclimatic potentiality of a given area includes the moisture availability, stress free crop growing period, frequency of dry and wet spells etc. throughout the year. Selection of crops and crop cultivars in a particular region is usually based on the Length of Growing Period (LGP) which is measured in terms of weeks (Thirupathi et al., 2015). Length of stress free crop growing period is determined by the weekly moisture adequacy index (MAI) value which is affected by the onset and cessation of the monsoon (June to September) rainfall. LGP is usually computed from the balance of available moisture in the soil and atmospheric demand. The weeks having MAI value of 0.5 and more are considered as the stress free crop growing period and cropping seasons are adjusted in such a way that the crops experience minimal or no stress (Reddy et al., 
2001; Sattar and Khan, 2017). Length of the growing period also includes the period of soil moisture storage during post-monsoon season (October to February). Successful crop planning and soil-water conservation measures are notably influenced by the sequence of wet and dry spells. The probability of climatological risk caused by dry spells can be determined by Markov Chain model. Several researches were dedicated to determine the frequency ofdry and wet spells in a year along with the probability of occurring dry and wet spells by analyzing rainfall time series data using Markov chain model (Joseph and Tamilmani, 2017; Dugalet al., 2018).

Indian Sundarbans, one of the most ecologically fragile regions in India and in the world, comes under the coastal saline agroclimaticzone of West Bengal. Geographical extent of Indian Sundarbans makes the region very much vulnerable from climatological viewpoints. Being located in the coastal zone, Indian Sundarbans region experiences a lot of natural calamities (Ray et al., 2019; Sarkar et al., 2019). It was reported that the average annual rainfall and the number of rainy days decreased in Indian Sundarbans area during the last decade (Mandal et al., 2019). In order to mitigate the vagaries of monsoon behavior, proper crop planning is essential for sustainable crop production in the area. In order to increase the cropping intensity of Indian Sundarbans, crop production opportunities and limitations during the post-monsoon seasons should be assessed. As the post-monsoon season in the Indian Sundarbans area is almost dry, crop production is mostly rainfed and depends on the residual soil moisture (Ghosh et al., 2019; Sarkar et al., 2020). Mono-cropping of kharif rice is the general practice in this area and during winter and summer season, a number of crops including grass pea, potato, vegetables, green gram boro rice were grown. Crop planning is essential for efficient utilization of residual soil moisture by selecting proper cropping window. Previous studies revealed the climatological vulnerability of the Indian Sundarbans region. Variation in the crop productivity in relation to the rainfall variability was reported earlier (Mandal et al., 2013; Mandal and Choudhury, 2015; Mandal et al., 2015; Mandal et al., 2018). The present study aimed at determining the climatological risk for crop production and LGP in Indian Sundarbans area using the long term rainfall data.The objective of this study was to identify the promising cropping systems for sustainable cropping intensification.

\section{MATERIALS AND METHODS}

\section{Study area}

The present study was conducted in the Gosaba CD block, South 24 Pgs. of Indian Sundarbans. The block extends from $22^{\circ} 18^{\prime} \mathrm{N}$ in the North to $22^{\circ} 3^{\prime} \mathrm{N}$ in the South and $88^{\circ} 57^{\prime} \mathrm{E}$ in the East to $88^{\circ} 39^{\prime} \mathrm{E}$ in the West. Gosaba CD block is the last inhabited area before the dense mangrove forest starts. Average annual temperature varies from $35^{\circ} \mathrm{C}$ in July to $17^{\circ} \mathrm{C}$ in January. Average annual rainfall is 1920 mm major proportion of which occurs from June to September due to South West Monsoon. The area is characterized by heavy textured soil including silty clay, clay loam etc. with salinity ranged from 4.5 to $5.8 \mathrm{ppt}$. Soil is slightly alkaline in nature with $\mathrm{pH}$ ranged between 8.0 and 8.3 (Debnath, 2018). The study area is situated in the largest coastal marine ecosystem in India and thereby is very much susceptible to frequent cyclones, storm surges, floods; intrusion of saline water etc. (Ray et al., 2019; Sarkar et al., 2019). Cropping intensity of this area is low because major proportion of the cultivable land remains fallow during the post-monsoon season.

\section{Data source}

Daily rainfall data with a spatial resolution of $0.5^{\circ} \mathrm{X}$ $0.5^{\circ}$ from January, 1984 to September, 2017 was collected from the open data archive of NASA data access viewer (power.larc.nasa.gov/data-access-viewer/).Daily rainfall data from October, 2017 to December, 2018 was recorded in the Automatic Weather Station installed in the study area.

\section{Rainfall probability analysis}

Weekly total rainfall $(\mathrm{mm})$ averaged over the 35 years period was calculated along with the standard deviations, coefficient of variations and coefficients of skewness. Weekly rainfall values were arranged in descending order of magnitude and each value was assigned with a particular rank $(m)$ for each and every week. The probability (p) of a rainfall event was calculated by Weibull's formula as followed by Subudhi et al. (2016) and the rainfall events with $25 \%$, $50 \%, 75 \%$ probabilities were estimated

$$
\begin{aligned}
& \mathrm{P}=\mathrm{m} /(\mathrm{N}+1) \\
& \text { Where, } \mathrm{N} \text { - number of years (35 years) }
\end{aligned}
$$

\section{Assessment of climatological risk}

Climatological risk caused by seasonal drought was assessed in terms of dry and wet week probabilities by using Markov Chain model (Dugalet al., 2018). Initial and conditional probabilities of occurrence of dry and wet weeks and probabilities of occurring two consecutive dry and wet weeks were calculated considering rainfall threshold of 10 
$\mathrm{mm}$ and $20 \mathrm{~mm}$ because these amount of weekly rainfall are relevant for agricultural operations and crop growth (Pawaret al., 2015; Dugalet al., 2018).

\section{Initial rainfall probability of a week being dry or wet}

$$
\mathrm{P}(\mathrm{D})=\mathrm{F}(\mathrm{D}) / \mathrm{N} ; \mathrm{P}(\mathrm{W})=\mathrm{F}(\mathrm{W}) / \mathrm{N}
$$

Where, P(D) - Probability of the week being dry; P(W) - Probability of the week being wet; F(D) - Number of dry weeks; F(W) - Number of wet weeks; N - Number of years (35 years)

\section{Conditional probability of a week being dry or wet}

$$
\mathrm{P}(\mathrm{DD})=\mathrm{F}(\mathrm{DD}) / \mathrm{F}(\mathrm{D}) ; \mathrm{P}(\mathrm{WW})=\mathrm{F}(\mathrm{WW}) / \mathrm{F}(\mathrm{W}) ; \mathrm{P}(\mathrm{DW})
$$

$=1-\mathrm{P}(\mathrm{DD}) ; \mathrm{P}(\mathrm{WD})=1-\mathrm{P}(\mathrm{WW})$

Where, P(DD) - Probability of a dry week preceded by a dry week; P(WW) - Probability of a wet week preceded by a wet week; P(WD) - Probability of a wet week preceded by a dry week; P(DW) - Probability of a dry week preceded by a wet week; F(DD) - Number of dry weeks preceded by another dry week; F(WW) - Number of wet weeks preceded by another wet week

\section{Consecutive dry and wet week probabilities} $\mathrm{P}\left(\mathrm{WWW}_{2}\right)$

$$
2(\mathrm{D})=\mathrm{P}\left(\mathrm{DW}_{1}\right) \mathrm{XP}\left(\mathrm{DDW}_{2}\right) ; 2(\mathrm{~W})=\mathrm{P}\left(\mathrm{WW}_{1}\right) \mathrm{X}
$$

Where, 2(D) - Probability of 2 consecutive dry weeks starting with the week; 2(W) - Probability of 2 consecutive wet weeks starting with the week; $\mathrm{P}\left(\mathrm{DW}_{1}\right)$ - Probability of the week being dry (first week); $\mathrm{P}\left(\mathrm{DDW}_{2}\right)$ - Probability of the second week being dry, given the preceding week dry; $\mathrm{P}\left(\mathrm{WW}_{1}\right)$ - Probability of the week being wet (first week); $\mathrm{P}\left(\mathrm{WWW}_{2}\right)$ - Probability of the second week being wet, given the preceding week wet

\section{Estimation of moisture availability}

Weekly moisture availability was estimated by calculating the moisture adequacy index (MAI) using the water balance model of Thornthwaite and Mather (1955). New_LockClim 1.10 software developed by FAO was used to calculate weekly potential evapotranspiration (PET) and in Sundarbans regions. WeatherCock 1.0 software developed by Central Research Institute for Dryland Agriculture (CRIDA) was used to calculate weekly actual evapotranspiration (AET) and MAI values. MAI was calculated considering $150 \mathrm{~mm} / \mathrm{m}$ water holding capacity of the study area as extracted from Harmonized World Soil Database 1.2 (Fischer et al., 2008) using the formula:

\section{$\mathrm{MAI}=\mathrm{AET} / \mathrm{PET}$}

\section{Determination of length of growing period (LGP)}

The length of growing period was calculated using the MAI values computed by the water balance model of Thornthwaite and Mather (1955). Growing season started when MAI values of two or more consecutive weeks became greater than 0.5 and growing season terminated when MAI value of a week became lesser than 0.33 . LGP was calculated for of all the years and the average LGP of the study area was determined.

According to Krishnan et al. (1980), the weeks having AET / PET value equals to or greater than 0.5 is denoted by drought free growing period, AET / PET value between lesser than 0.5 and 0.25 is denoted by moderate drought period and AET / PET value lesser than 0.25 is denoted by severe drought period. In the present study the probabilities of each and every week being drought free period, moderately drought period or severe drought period was calculated using the MAI values.

\section{RESULTS AND DISCUSSION}

\section{Rainfall and actual evapotranspiration (AET)}

Weekly rainfall averaged over 35 years (1984-2018) along with standard deviation, coefficient of variation and coefficient of skewness has been represented in the Table 1 . It was observed that weekly rainfall varied from $1.11 \mathrm{~mm}$ in $51^{\text {st }}$ Standard Meteorological Week (SMW) with standard deviation of \pm 3.41 to $88.49 \mathrm{~mm}$ in $29^{\text {th }} \mathrm{SMW}$ with standard deviation of \pm 58.19 . Variability of weekly rainfall was demonstrated by the coefficient of variation which showed that variability in weekly rainfall during monsoon season (22 $2^{\text {nd }}$ SMW to $39^{\text {th }}$ SMW) was lesser as compare to that variability in weekly rainfall during the rest of the year. The lowest variability was observed in $31^{\text {st }} \mathrm{SMW}(\mathrm{CV}=47.89 \%)$ while the highest variability was found in $48^{\text {th }} \mathrm{SMW}(\mathrm{CV}=$ $533.07 \%$ ). Results also revealed that the coefficient of skewness varied from 0.06 in $26^{\text {th }} \mathrm{SMW}$ to 5.88 in $48^{\text {th }} \mathrm{SMW}$.

Rainfall probability analysis was carried out by following Weibull's formula to estimate the expected rainfall at $25 \%, 50 \%$ and $75 \%$ probabilitylevel (Fig. 1). Throughout the year, the lowest amount of weekly rainfall was expected at $75 \%$ probability level followed by $50 \%$ and $25 \%$ probability level. It was observed that the period extending from $24^{\text {th }}$ SMW to $38^{\text {th }}$ SMW and from $23^{\text {rd }}$ SMW to $41^{\text {st }} \mathrm{SMW}$ exhibited the $75 \%$ chance of getting more than $20 \mathrm{~mm}$ and $10 \mathrm{~mm}$ weekly rainfall respectively. On the other hand $50 \%$ 


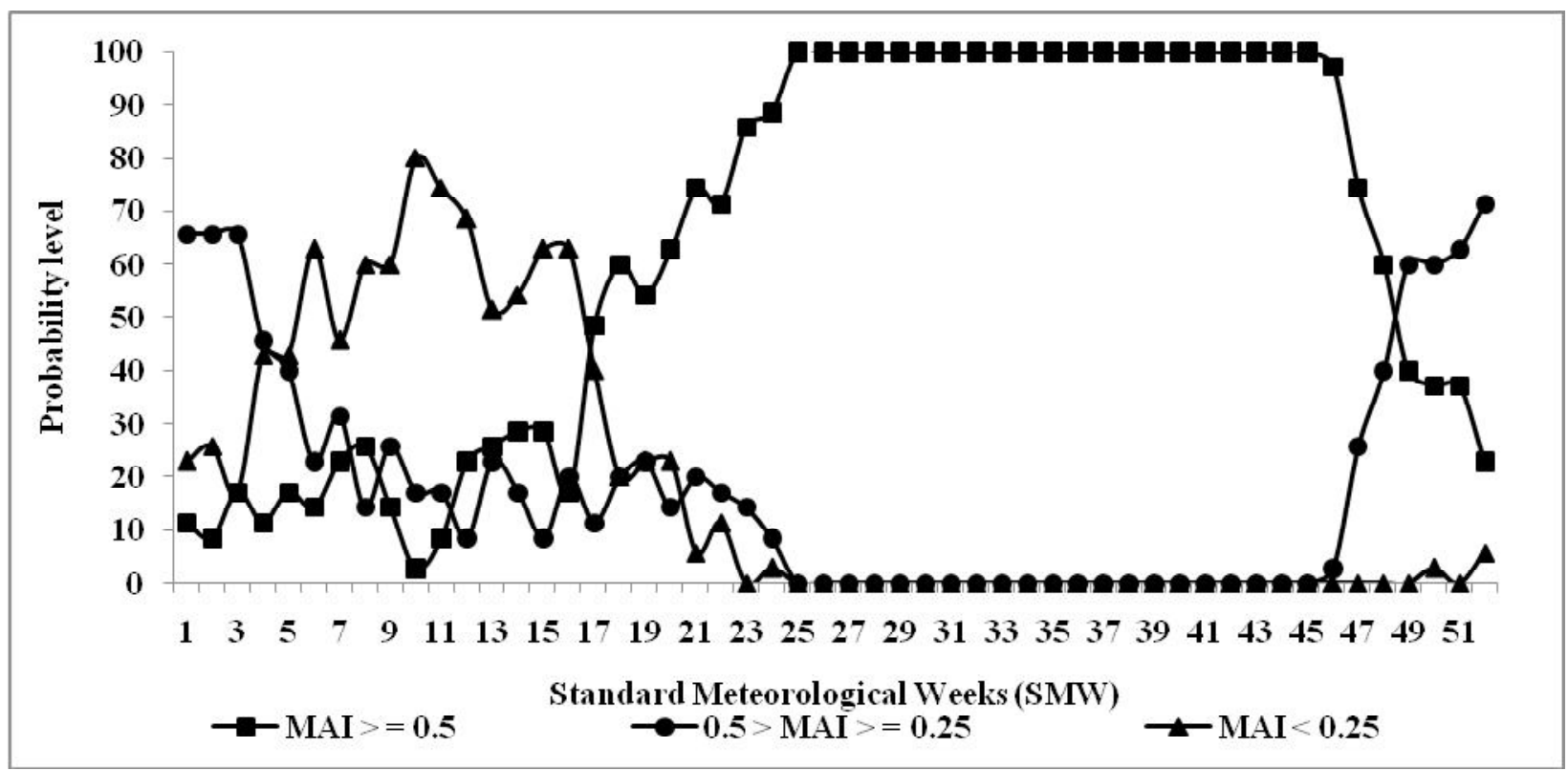

Fig. 1: Weekly rainfall expected at $25 \%, 50 \%$ and $75 \%$ probability level

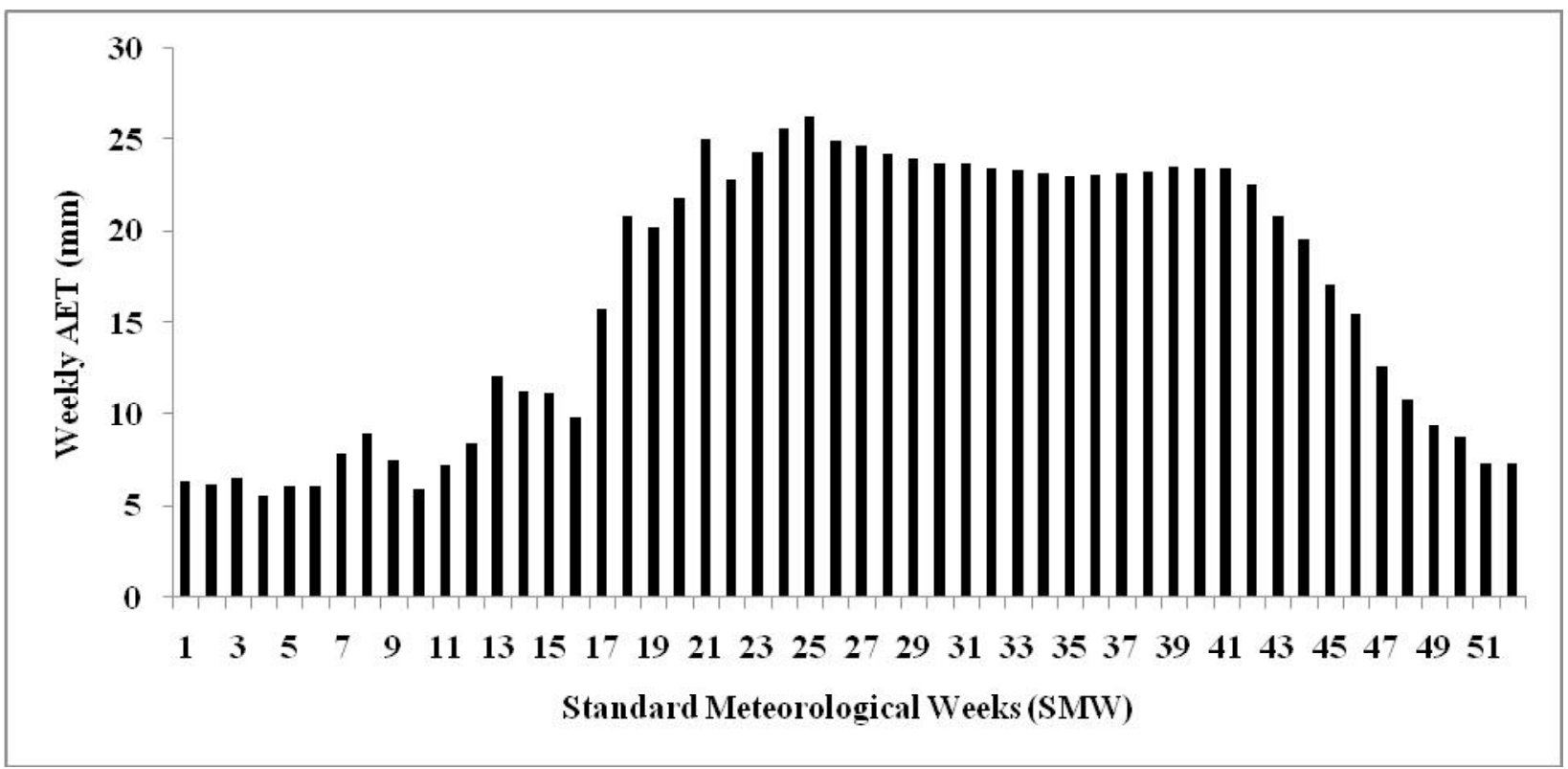

Fig. 2: Weekly Actual evapotranspiration averaged over 35 years (1984-2018)

chance of getting more than $20 \mathrm{~mm}$ and $10 \mathrm{~mm}$ weekly rainfall was observed from $20^{\text {th }} \mathrm{SMW}(23.37 \mathrm{~mm})$ to $41^{\text {st }}$ SMW (30.64 mm) and $17^{\text {th }}$ SMW $(14.63 \mathrm{~mm})$ to $42^{\text {nd }} \mathrm{SMW}$ $(16.87 \mathrm{~mm})$ respectively. Weekly rainfall variability and probability analysis was conducted earlier for irrigation planning, contingent crop planning etc. in a given area using the same methodology followed in the present study (Pawaret al., 2015; Ray, 2016). Weekly rainfall assured at 50 $\%$ probability level is of the prime importance because it is used to compute the optimum moisture adequacy index as developed by Sarkar and Biswas (1988).
Actual evapotranspiration(AET), computed on weekly basis by the water balance model of Thornthwaite and Mather (1955) has been presented in the Fig. 2. Average AET varied from $5.59 \mathrm{~mm}$ in $4^{\text {th }} \mathrm{SMW}$ to $26.26 \mathrm{~mm}$ in $25^{\text {th }} \mathrm{SMW}$. It was observed that weekly AET started to rise from $17^{\text {th }}$ SMW attaining its peak in $25^{\text {th }}$ SMW and remained higher up to $41^{\text {st }}$ SMW. Thereafter AET gradually declined.

\section{Probabilities of dry and wet weeks}

In order to determine the initial and conditional probabilities of a week getting more than $10 \mathrm{~mm}$ and $20 \mathrm{~mm}$ 


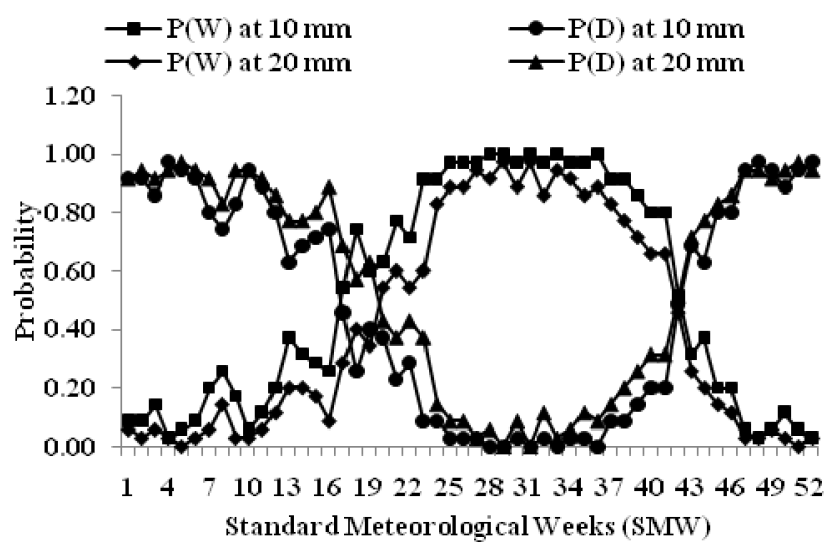

3a: Initial probability of wet $[\mathrm{P}(\mathrm{W})]$ and dry $[\mathrm{P}(\mathrm{D})]$ weeks

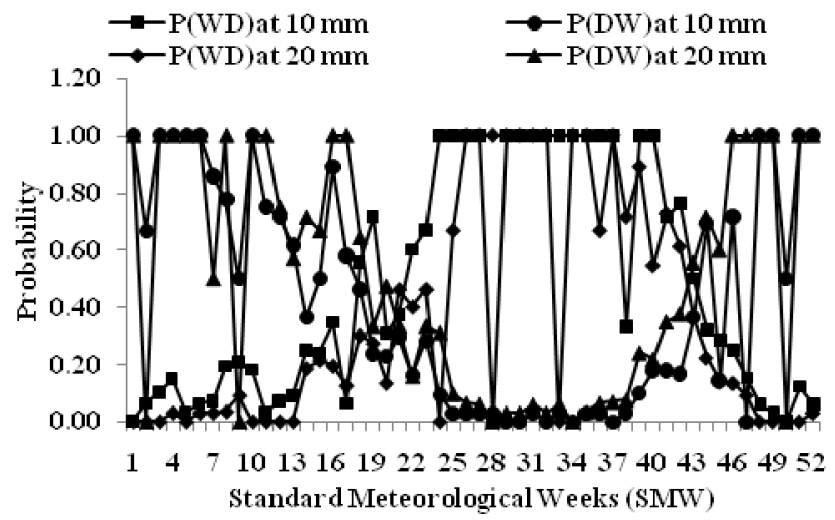

3c: Conditionalprobability of wet week preceded by dry week $[\mathrm{P}(\mathrm{WD})]$ and dry week preceded by wetweek $[\mathrm{P}(\mathrm{DW})]$

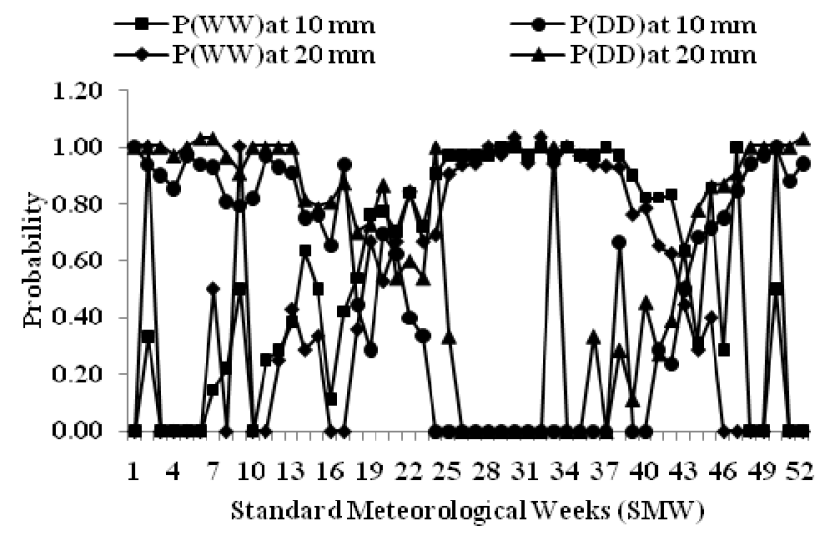

3b: Conditionalprobability of wet week preceded by wet week $[\mathrm{P}(\mathrm{WW})]$ and Dry week preceded by dry week $[\mathrm{P}(\mathrm{DD})]$

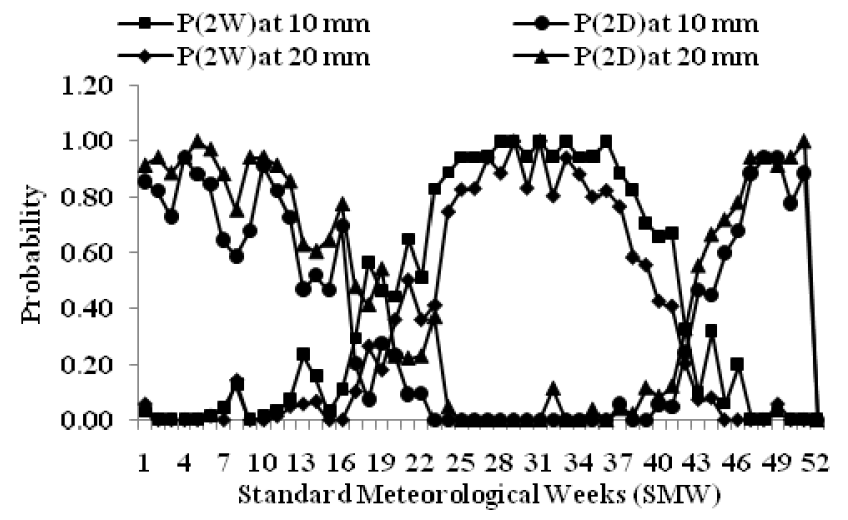

$3 \mathrm{~d}$ : Probability of two consecutive wet $[\mathrm{P}(\mathrm{WW})]$ and dry [P(DD)] weeks

Fig. 3: Initial, conditional and consecutive probabilities of dry and wet weeks for $10 \mathrm{~mm}$ and $20 \mathrm{~mm}$ threshold rainfall

rainfall, Markov chain model was used. The initial probabilities of a week being wet and dry considering the two rainfall threshold values have been shown (Fig. 3a). It was found that the initial probability of getting more than 10 $\mathrm{mm}$ rainfall is more than that of getting more than $20 \mathrm{~mm}$ rainfall for all the weeks. This trend is same for the conditional probabilities (Fig. 3b and 3c) and probability of getting two consecutive wet or dry weeks (Fig. 3d).

Results revealed that during monsoon season $\left(22^{\text {nd }}\right.$ to $39^{\text {th }} \mathrm{SMW}$ ), initial probability of getting more than $10 \mathrm{~mm}$ and $20 \mathrm{~mm}$ weekly rainfall $[\mathrm{P}(\mathrm{W})]$ varied from $71 \%\left(22^{\text {nd }}\right.$ SMW $)$ to $100 \%\left(28^{\text {th }}, 29^{\text {th }}, 31^{\text {st }}, 33^{\text {rd }}\right.$ and $\left.36^{\text {th }} \mathrm{SMW}\right)$ and 54 $\%$ (22th SMW) to $97 \%\left(29^{\text {th }}\right.$ and $31^{\text {st }}$ SMW $)$ respectively. During the post-monsoon period, $[\mathrm{P}(\mathrm{W})]$ of a week receiving more $10 \mathrm{~mm}$ rainfall was more than $30 \%$ from $40^{\text {th }} \mathrm{SMW}$ to $44^{\text {th }}$ SMW while the probability remained more than $20 \%$ for getting more than $20 \mathrm{~mm}$ rainfall during the same period. In case of pre-monsoon period, $[\mathrm{P}(\mathrm{W})]$ was more than $25 \%$ from $13^{\text {th }}$ SMW to $21^{\text {st }}$ SMW and from $17^{\text {th }}$ SMW to $21^{\text {st }}$ SMW considering $10 \mathrm{~mm}$ and $20 \mathrm{~mm}$ rainfall thresholds respectively.

Conditional probability of a week being wet preceded by a wet week $[\mathrm{P}(\mathrm{WW})]$ varied from almost $70 \%$ to $100 \%$ during monsoon season for two threshold rainfall values. $[\mathrm{P}(\mathrm{WW})]$ was observed to become more than $25 \%$ from $11^{\text {th }}$ SMW to $21^{\text {st }}$ SMW except $16^{\text {th }}$ SMW for more than $10 \mathrm{~mm}$ rainfall and from $12^{\text {th }} \mathrm{SWM}$ to $21^{\text {st }} \mathrm{SMW}$ except $16^{\text {th }}$ and $17^{\text {th }}$ SMW. During pre-monsoon and post-monsoon periods, $[\mathrm{P}(\mathrm{WW})]$ values were found lower. The conditional probability of a wet week preceded by a dry week [P(WD)] was higher during monsoon season and lower during premonsoon and post-monsoon seasons. The result is just the opposite for the probability of a dry week preceded by a wet week $[\mathrm{P}(\mathrm{DW})]$. The period extending from $18^{\text {th }} \mathrm{SMW}$ to $41^{\text {st }}$ SMW exhibited more than $40 \%$ chance of occurring two consecutive wet weeks $[\mathrm{P}(2 \mathrm{~W})]$ having more than $10 \mathrm{~mm}$ rainfall. $[\mathrm{P}(2 \mathrm{~W})]$ remained more than $40 \%$ from $23^{\text {rd }} \mathrm{SMW}$ 
Table 1: Rainfall variability over 35 years (1984-2018) in the study area

\begin{tabular}{|c|c|c|c|c|c|c|c|c|c|}
\hline SMW & Mean & $\mathrm{SD}( \pm)$ & CV $(\%)$ & $\mathrm{CS}$ & SMW & Mean & $\mathrm{SD}( \pm)$ & CV $(\%)$ & $\mathrm{CS}$ \\
\hline 1 & 2.47 & 7.63 & 308.87 & 3.93 & 27 & 84.57 & 56.89 & 67.28 & 1.79 \\
\hline 2 & 2.10 & 5.84 & 278.60 & 3.05 & 28 & 74.89 & 50.79 & 67.82 & 1.52 \\
\hline 3 & 3.10 & 6.61 & 213.15 & 2.83 & 29 & 88.49 & 58.19 & 65.76 & 2.05 \\
\hline 4 & 2.42 & 8.54 & 353.54 & 5.24 & 30 & 74.95 & 57.28 & 76.43 & 1.90 \\
\hline 5 & 2.26 & 3.76 & 166.23 & 1.97 & 31 & 74.63 & 35.74 & 47.89 & 1.11 \\
\hline 6 & 2.37 & 5.43 & 229.02 & 2.99 & 32 & 77.85 & 61.05 & 78.42 & 1.76 \\
\hline 7 & 4.63 & 7.41 & 160.03 & 1.77 & 33 & 68.40 & 34.86 & 50.97 & 0.73 \\
\hline 8 & 7.26 & 13.47 & 185.62 & 2.89 & 34 & 66.93 & 46.92 & 70.11 & 1.61 \\
\hline 9 & 4.12 & 6.89 & 167.42 & 1.71 & 35 & 58.33 & 33.47 & 57.37 & 0.48 \\
\hline 10 & 3.72 & 12.16 & 326.65 & 5.50 & 36 & 62.46 & 47.07 & 75.35 & 2.08 \\
\hline 11 & 6.27 & 15.72 & 250.65 & 3.84 & 37 & 58.86 & 46.12 & 78.36 & 1.54 \\
\hline 12 & 7.21 & 14.75 & 204.50 & 3.36 & 38 & 65.02 & 61.38 & 94.40 & 1.75 \\
\hline 13 & 10.64 & 12.62 & 118.60 & 1.31 & 39 & 56.79 & 58.79 & 103.52 & 2.45 \\
\hline 14 & 9.93 & 14.72 & 148.14 & 1.81 & 40 & 44.58 & 41.75 & 93.64 & 1.42 \\
\hline 15 & 10.19 & 16.61 & 163.05 & 2.82 & 41 & 37.50 & 37.74 & 100.63 & 2.95 \\
\hline 16 & 7.63 & 10.98 & 143.92 & 1.96 & 42 & 32.52 & 47.85 & 147.16 & 2.43 \\
\hline 17 & 15.50 & 15.59 & 100.60 & 1.23 & 43 & 17.43 & 31.48 & 180.55 & 2.43 \\
\hline 18 & 24.05 & 21.90 & 91.06 & 1.71 & 44 & 12.12 & 17.09 & 140.97 & 1.66 \\
\hline 19 & 21.85 & 18.69 & 85.51 & 0.43 & 45 & 10.48 & 26.08 & 248.75 & 3.54 \\
\hline 20 & 33.20 & 38.19 & 115.01 & 2.23 & 46 & 6.91 & 14.07 & 203.53 & 2.58 \\
\hline 21 & 36.88 & 35.91 & 97.35 & 2.11 & 47 & 3.36 & 14.38 & 427.45 & 5.73 \\
\hline 22 & 32.20 & 28.78 & 89.37 & 1.04 & 48 & 2.79 & 14.90 & 533.07 & 5.89 \\
\hline 23 & 43.09 & 48.88 & 113.42 & 3.02 & 49 & 2.14 & 8.56 & 400.47 & 4.17 \\
\hline 24 & 71.24 & 52.38 & 73.53 & 1.19 & 50 & 2.58 & 5.47 & 212.45 & 2.36 \\
\hline 25 & 72.64 & 40.88 & 56.28 & 0.94 & 51 & 1.11 & 3.41 & 306.57 & 3.58 \\
\hline 26 & 74.54 & 39.54 & 53.04 & 0.06 & 52 & 1.69 & 6.26 & 371.04 & 5.27 \\
\hline
\end{tabular}

SMW: Standard Meteorological Week; SD: Standard deviations; CV: Coefficient of variation, CS: Coefficient of skewness

to $41^{\text {st }} \mathrm{SMW}$ when the threshold values was considered as $20 \mathrm{~mm}$. Initial probability of dry week [P(D)], conditional probability of dry week preceded by dry week [P(DD)], dry week preceded by wet week $[\mathrm{P}(\mathrm{DW})]$ and probability of two consecutive dry weeks showed higher values during winter and summer seasons. The result so obtained in the present study was in agreement with previous studies conducted in the same climatic regions (Dugalet al., 2018; Behera and Subudhi, 2018).

\section{Length of growing period}

Length of growing period (LGP) was calculated from the MAI values computed by the water balance method of
Thornthwaite and Mather (1955). Results revealed that LGP varied from 182 days in the year 1984 to 302 days in the year 2017 (Fig. 4). The present study showed that the average LGP of the study area was 237.4 days with standard deviation of \pm 29.88 and $12.58 \%$ variability.

In order to determine the drought proneness of a week in a year, the probability of moisture availability of each and every week was calculated and presented (Fig.5). Probability of a week being drought free growing period remained more than $50 \%$ continuously from $18^{\text {th }}$ SMW to $48^{\text {th }}$ SMW. The period extending from $49^{\text {th }}$ SMW to $6^{\text {th }}$ SMW exhibited $40 \%$ to $71 \%$ probability of having MAI value 


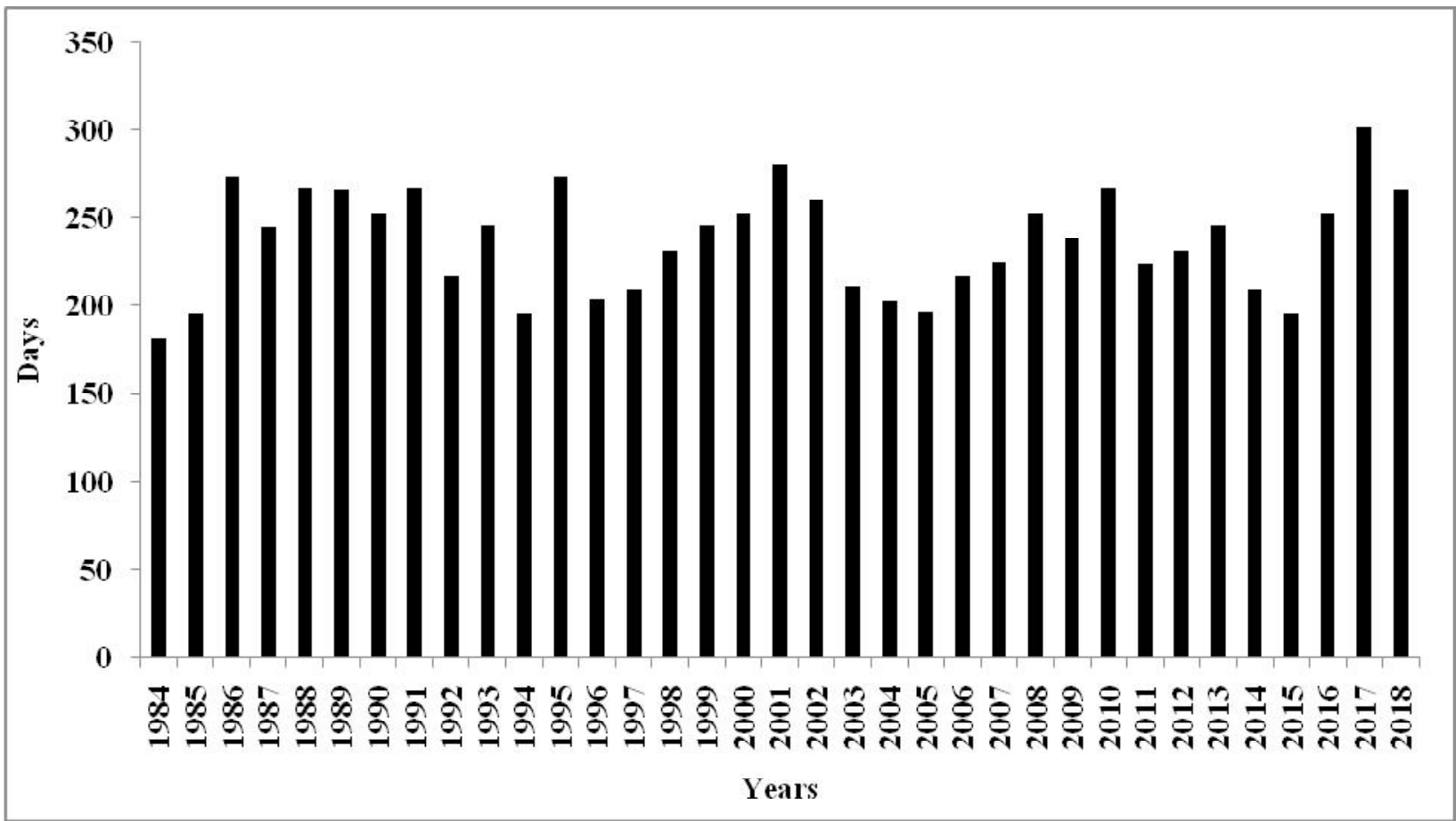

Fig. 4: Length of growing period (days) from 1984 to 2018

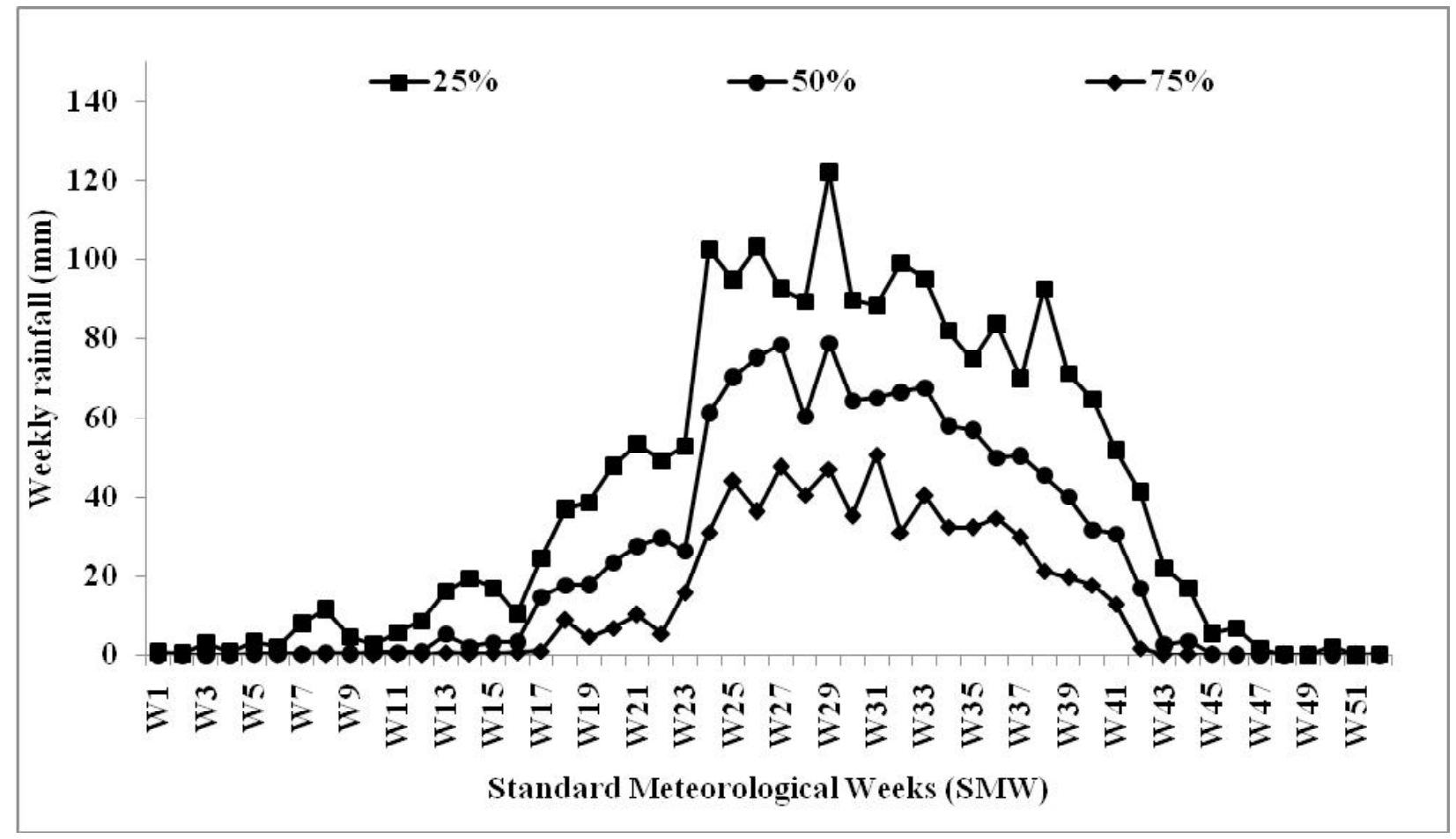

Fig. 5: Probability of a week being drought free crop growing period (MAI $>=0.5$ ), moderately drought period $(0.5>\mathrm{MAI}>=0.25)$ and severe drought period $(\mathrm{MAI}<0.25)$

lesser than 0.50 to equals to or more than 0.25 which proved this period as moderate drought period. On the contrary the period extending from $6^{\text {th }}$ SMW to $17^{\text {th }}$ SMW associated with $40 \%$ to $80 \%$ probability of being severe drought weeks.

\section{Cropping systems suitable for the study area}

In the study area, generally rice (kharif) - fallow (rabi) - fallow (pre-kharif), rice (kharif) - grass pea (rabi) fallow (pre-kharif), rice (kharif) - potato (rabi) - fallow 
(pre-kharif), rice (kharif)-fallow (rabi) - green gram (prekharif) and rice (kharif) -vegetables (rabi or pre-kharif) cropping systems are generally practiced. $\mathrm{P}(\mathrm{W})$ for both 10 $\mathrm{mm}$ and $20 \mathrm{~mm}$ weekly rainfall is more than $50 \%$ from $20^{\text {th }}$ SMW and onwards which favours nursery sowing, land preparation and transplanting of kharif rice. In rabi season, grass pea can be grown successfully in relay cropping system (Sarkar et al., 2020) as the period extending from $44^{\text {th }}$ SMW to $6^{\text {th }}$ SMW exhibited higher possibilities of being drought free crop growing period and moderate drought period. As grass pea is a drought tolerant crop, it can be cultivated under moderate drought condition. In India Sundarbans region, potato is generally grown under zero tillage condition with straw mulch which requires fewer amounts of rainfall and thereby less number of irrigation also (Saha et al., 1997). Therefore potato can be successfully cultivated with straw mulch with limited irrigation when required. During summer season, $\mathrm{P}(\mathrm{W})$ and $\mathrm{P}(\mathrm{WW})$ for getting more than $10 \mathrm{~mm}$ weekly rainfall is more than $20 \%$ from $12^{\text {th }}$ and $11^{\text {th }}$ SMW respectively. Short duration green gram cultivars can be grown in this area during summer season with light irrigation if required. Bororice requires lot of irrigation which induces the soil salinity and this discourages the cultivation of boro rice in Indian Sundarbans region. Winter and summer vegetables also need higher amount irrigation water. So, rice - grass pea - fallow, rice potato (straw mulch) - fallow, rice - fallow - green gram are the most promising cropping systems for the study area.

\section{CONCLUSION}

The preset study estimated the rainfall probability in the study area throughout the year along with the climatological risk of dry spells. Weekly rainfall is highly variable during winter and summer season. More than $20 \mathrm{~mm}$ and $10 \mathrm{~mm}$ weekly rainfall is expected at $50 \%$ probability levelduring the period extended from $20^{\text {th }} \mathrm{SMW}$ to $41^{\text {st }} \mathrm{SMW}$ and $17^{\text {th }}$ SMW to $42^{\text {nd }}$ SMW respectively. The risk of dry spells was very higher from $42^{\text {nd }}$ to $17^{\text {th }}$ SMW. Probability of a week being stress free growing period and moderately drought period was more than $50 \%$ from $18^{\text {th }}$ to $48^{\text {th }} \mathrm{SMW}$ and $49^{\text {th }}$ to $5^{\text {th }}$ SMW respectively. On the basis of the results found it the present study, it is evident that grass pea, potato with straw mulch and green gram can be included in the rice based cropping system during winter and summer seasons for sustainable intensification of the cropping systems in Indian Sundarbans region.

\section{ACKNOWLEDGEMENT}

The study is funded by the Australian Centre for International Agricultural Research through the project 'Cropping system intensification in the salt-affected coastal zones of Bangladesh and West Bengal India' (LWR/2014/ 073).

\section{REFERENCES}

Adhikari, R. N., Mishra, P. K., andSeshadri, B. N. (2012). Drought Analysis of BellaryRegion in Karnataka. Indian J. Dryland Agric. Res. Develop., 27(1), 29-36.

Behera, S. and Subudhi, C. R. (2018). Markov Chain Model of Weekly Rainfall Probabilityand Dry and Wet Spells for Agricultural Planning in Ganjam District of Odisha. Int. J. Pharm. Pharm. Sci., 12(3): 422-433

Dash, A. and Shatpathy, P. (2018). Probability Analysis of Rainfall Distribution in Sambalpur District of Odisha. $J$ PharmacognPhytochem, 7(5), 3169-317.

Debnath, A. (2018). Land Use and Land CoverChange Detection of Gosaba Island of the Indian Sundarban Region by Using Multitemporal Satellite Image.Int. J. Hum. Soc. Sci. 7(1): 209-217.

Deo, K., Tripathi, P., Kumar, A., Singh, K., Mishra, S., Mishra, A. and Singh, A. J. (2015). Trend of rainfall in different sectors of Uttar Pradesh under present scenario of climate change. Int. J. Environ. Sci, 6, 303-310.

Dugal, D., Mohapatra, A. K. B., Pasupalak, S., Rath, B. S., Baliarsingh,A., Khuntia,A. andPanigrahi,A. N.G. (2018). Crop planning based on rainfall probability for Bhadrak district of Odisha. Pharma Innovation. 2018; 7(11): 162-167

Fischer, G., Nachtergaele, F., Prieler, S., Van Velthuizen, H. T., Verelst, L. and Wiberg, D. (2008). Global agro-ecological zones assessment for agriculture (GAEZ2008). IIASA, Laxenburg, Austria and FAO, Rome, Italy, 10.

Ghosh,A., Nanda, M. K., Sarkar, D., Sarkar, S., Brahmachari, K. and Ray, K. (2019)Application of Multi-dated Sentinel2 Imageries to Assess the Cropping System in Gosaba Island of Indian Sundarbans. JIndian Soc. Coastal Agric. Res., 37(2), 32-44.

Joseph, A. and Tamilmani, D. (2017). Markov Chain Model of weekly rainfall probability and dry and wet spells for agricultural planning in Coimbatore in western zone of Tamil Nadu. Indian J. Soil Conser., 45(1), 66-71.

Krishnan, A., Ramakrishna, Y. S. andSastry,A. S. R. A. S. (1980). System analysis for crop planning in Jodhpur district. 
Indian J. Agric. Sci, 50(5), 412-21.

Kumar, R. and Bhardwaj, A. (2015). Probability analysis of return period of dailymaximum rainfall in annual data set of Ludhiana, Punjab. Indian J. Agric. Res., 49(2), 160164.

Mandal, S., Choudhury, B. U., Mondal, M. and Bej, S. (2013). Trend analysis of weather variables in Sagar Island, West Bengal, India: a long-term perspective (1982-2010). Current Sci., 947-953.

Mandal, S. and Choudhury, B. U. (2015). Estimation and prediction of maximum daily rainfall at Sagar Island using best fit probability models. Theor.and Appl.Climatol., 121(1-2): 87-97.

Mandal, S., Choudhury, B. U. and Satpati, L. N. (2015). Monsoon variability, crop water requirement, and crop planning for kharif rice in Sagar Island, India. Int. J.Biometeorol., 59(12), 1891-1903.

Mandal, S., Satpati, L. N., Choudhury, B. U. and Sadhu, S. (2018). Climate change vulnerability to agrarian ecosystem of small Island: evidence from Sagar Island, India. Theor. and Appl. Climatol., 132(1-2): 451-464.

Mandal, U. K., Nayak, D. B., Mullick, S., Samui,A., Jana,A. K., Mahanta, K.K., ... and Burman, D. (2019). Trend analysis of weather parameters over Indian Sundarbans. $J$. Agrometeorol, 21(3), 307-315.

Manikandan, M., Thiyagarajan, G., Bhuvaneswari, J. andPrabhakaran, N. K. (2016). WetAnd DrySpell Analysis For Agricultural Crop Planning Using Markov Chain Probability Model at Bhavanisagar.Int. J. Math. Comp. Appl. Res., 7(1): 11-22

Mehta, T. and Chandra, H. (2016). Probability Analysis of Rainfall at Udham Singh Nagar, Uttarakhanad. Int. $J$. Res. Eng. Appl. Sci., 6(11): 56-66

Pawar, P. B., Jadhav, J. D., Patil, S. R. and Amrutsagar, A. M. (2015). Weekly rainfall variability and probability analysis for Solapur in respect of crop planning. Ecoscan, 9(1\&2), 117-122.

Power DataAccess Viewer. NASA. https://power.larc.nasa.gov/ data-access-viewer/

Ray, M. (2016). Rainfall probability analysis for contingent crop planning in Keonjhar(Odisha). Asian J. Environ. Sci., 11(1), 106-110.
Ray, K., Brahmachari, M., Goswami, R., Sarkar, S., Brahmachari, K., Ghosh, A., and Nanda, M. K. (2019) Adoption of improved technologies for cropping intensification in the coastal zone of West Bengal, India: a village level study for impact assessment. J Indian Soc Coastal AgricRes, 37(2), 144-152.

Reddy, R. S., Naidu, L. G. K., Srinivas, S., Niranjana, K. V., Ramesh, M., Harindranath, C. S., ...andThayalan, S. (2001). Identification and categorization of agricultural drought-prone zones of Andhra Pradesh. Agropedology, 11, 101-109.

Saha, U. K., Hye, M.A., Haider, J. and Saha, R. R. (1997). Effect of rice straw mulch on the water use and tuber yield of potato grown under different irrigation schedules. Jpn J Trop Agr, 41(3), 168-176.

Sarkar, R. P. and Biswas, B. C. (1988). A new approach to agroclimatic classification to find out crop potential, Mausam, 39, 4: 343- 358.

Sarkar, S., Samui, I., Brahmachari, K., Ray, K., Ghosh, A. and Nanda, M. K. (2019) Management practices for utera pulses in rice-fallow system under coastal saline zone of West Bengal. J Indian Soc Coastal Agric Res, 37(2), 98-103.

Sarkar, S., Ghosh, A., Brahmachari, K., Ray, K., Nanda, M. K. and Sarkar,D. (2020). Weather relation of rice-grass pea crop sequence in Indian Sundarbans. J Agrometeorol, 22(2), 148-157.

Sattar, A. and Khan, S.A. (2017). Assessing climatic riskin terms of water availability to the crops in drought prone tract of Bihar. J Agrometeorol, 19 (Special Issue - AGMET 2016) $45-50$

Subudhi, C. R., Pradhan, R. andBarik, A. R. (2016). Probability analysis for prediction of annual maximum daily rainfall of Phulbaniblock of Kandhamal districtOdisha. J.Hum., Art. Med. Sci. 2(2): 65-76

Thirupathi, M., Shashikala, A. V. andPrabhakar, M. (2015). Variabilitystudy on the length of growing period (LGP) using ground and space based (MODIS) data for the selected mandals of Warangal district. Int. J.Advanc. $R$. Sens., GIS Geo., 3(2), 48-58.

Thornthwaite, C.W. and Mather, J. R. (1955). The water balance: Publication in Climatology, Drexel Institute of Technology, New Jersey. 8: 1-104. 